\title{
An Overview of TIG Welding of Ti6Al4V: Recent Developments
}

\author{
Peter O. Omoniyi ${ }^{1,2^{*}}$, Rasheedat M. Mahamood ${ }^{1,3}$, Tien-Chien Jen ${ }^{1}$, Esther T. Akinlabi ${ }^{1,4}$ \\ ${ }^{1}$ Department of Mechanical Engineering Science, University of Johannesburg, P. O. Box 524, Johannesburg, South Africa \\ ${ }^{2}$ Department of Mechanical Engineering, University of Ilorin, P. M. B. 1515, Ilorin, Nigeria \\ ${ }^{3}$ Department of Materials and Metallurgical Engineering, University of Ilorin, P. M. B. 1515, Ilorin, Nigeria \\ ${ }^{4}$ Pan African University for Life and Earth Sciences Institute (PAULESI), Ibadan 200132, Nigeria
}

Corresponding Author Email: omoniyi.po@unilorin.edu.ng

https://doi.org/10.18280/rcma.310501

Received: 14 July 2021

Accepted: 9 September 2021

\section{Keywords:}

microstructure, optimization, welding, TIG, titanium alloys

\begin{abstract}
Titanium is a commonly used non-ferrous metal in the aerospace, chemical and nuclear industry, due to its unique structural and mechanical properties. Selection of suitable welding techniques and understanding of the effects of parameters corroboration to achieve a quality joint necessitated this article. The article presents recent researches in process parameters optimization done on Tungsten Inert Gas (TIG) welding of Ti6Al4V alloy. Furthermore, it discusses the effects of the parameters used in TIG welding technique on the weld quality, mechanical properties, and microstructure of joined plates. Pulsed TIG welding was found to be the most suitable type of welding for Ti6Al4V alloys based on its ease of use and reduced heat input compared to the conventional TIG welding.
\end{abstract}

\section{INTRODUCTION}

Titanium and its alloys have predominately been a useful non-ferrous metal in numerous industries for years. The development of new and improved scientific approaches in engineering the titanium alloys over the years has further increased its uses in the biomedical, chemical, automobile, and aerospace sector [1-10]. The choice of this alloy over other types of alloys have been predominately due to some unique properties it possesses, some of these properties are low distortion rate during welding, fly-to-weight ratio, low corrosion rate, high meting point etc. [11-18].

Welding is one of the most economical techniques in joining metals permanently and a joining technique that is enormously been improved on in industries, using lasers and robots to carry out what the human capability cannot accomplish [19, 20]. Friction stir welding (FSW), laser beam welding (LBW), tungsten inert gas (TIG), electron beam welding (EBW) and metal inert gas (MIG) are common welding techniques used in joining of titanium and its alloys [21-26]. In the past, manual metal arc welding (MMAW) is majorly used in the welding of metals but has a major drawback of oxidation and vaporization of the melt pool, due to strong heat input [27]. These effects are eliminated with the use of flux or inert gases, in the cases of MIG and TIG to weld titanium and its alloys [21, 28]. To obtain sound welding, researchers need to have a good knowledge of the characteristics of the metal and the selection of suitable welder equipment.

Ti6Al4V is predominantly an $\alpha+\beta$ alloy, the elements which stabilize the $\alpha$ phase are called $\alpha$ stabilizers, they are Aluminum, Tin, Zirconium, while those that stabilizes the $\beta$ phase are called $\beta$ stabilizers, such as Vanadium, Iron and Molybdenum [7, 29-32]. Ti6Al4V alloy is highly sensitive to heat treatment processes such as annealing, solution heat treatment and ageing, which help in increasing the strength of the alloy by $50 \%$ [30, 33-35]. Typical components where Ti6Al4V alloys are used are hubs, compressor section of engines, blades, turbines etc. [36, 37].

TIG also referred to as gas tungsten arc welding (GTAW) or wolfram (tungsten) inert gas (WIG), is an easy, costeffective, uses non-consumable electrode and easily automated welding technique $[38,39]$. It could be operated in direct, alternating, or pulsed mode, In the case of direct mode, the electrode is negative, the workpiece is positive with a direct current applied. In alternating or pulse mode, the arc polarity swiftly changes, to give a cathodic cleaning effect. In pulsed mode, there is permission for an arc to be pulsed at different rates [21]. Other variants of TIG welding are activated-flux (A-TIG) welding, ultrasonic assisted TIG welding, flux bounded TIG (FBTIG), these are developed to improve penetration depth during welding [40, 41].

One of the major areas of the ineffectiveness of TIG, is in the requirement of high heat input for good penetration, resulting in high distortion and contamination of the weld, also is coarse grain and residual stress formation in the weld zone (WZ) [22]. However, at some welding stages, there are limitations to the extent at which the current can be maximized, due to the restricted current capacity of single electrodes and higher arc pressure [42]. To improve penetration and refine microstructure, activated flux paste are smeared on the surface of the workpiece before TIG welding is done [43-46]. The use of activated flux was reported by Gao et al. [10] to improve penetration at any given level of heat input, up to three times. They also postulated the reversal of Marangoni convection, which is the tendency of heat and mass to transfer to areas of higher surface tension in the weld pool and arc contraction rule 
to be the two key factors responsible for the increase of penetration depth in Activated flux-TIG welding. Activated surface tension elements such as oxygen, Sulphur and Selenium can reverse the Marangoni convection effect and cause the circulation of the weld fluid at the surface towards the weld pool. This consequently results in deeper weld penetration, and it is linked with the gradient of the surface tension of the weld pool [10, 47-49]. Pulsed current has also been established by researchers $[50,51]$ to reduce grain growth within the weld zone.

Therefore, this article gives a highlight of the benefits and disadvantages of the common TIG welding techniques used in industries, it further discusses the effect of the operating parameters of the various variant of the technique in conjunction with the microstructure and mechanical properties such as microhardness, tensile, corrosion and residual stress properties of welded Ti6Al4V alloys.

\section{TIG EXPERIMENTAL SETUP}

Titanium is one of the stress-free metals to weld using TIG, which can be operated manually and automatically [41, 52]. An arc between the workpiece and the tungsten alloy electrode, allows for the joining of metals, in the presence of inert gas such as argon or helium or combination of both gases which protects the welded area from atmospheric contamination [7, 53-55]. The gases also help in improving the penetration of electrode and welding speed $[15,56,57]$. Welding of titanium alloys using TIG can be autonomous (without filler) or with the use of filler wire. Parameters which affect the depth of penetration in TIG welding of Ti6Al4V alloys are arc voltage, root opening, welding current, shielding gas flow rate, travel speed, the electrode to work distance, filler metal feed rate [50, $58,59]$.

Figure 1 shows the experimental set up of the TIG welding process, where a butt joint is to be welded.

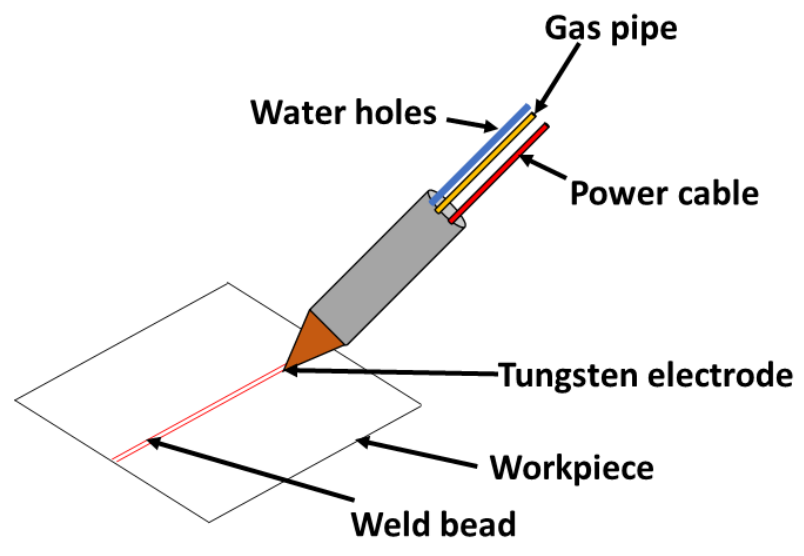

Figure 1. Schematics of TIG welding

\subsection{Appearance of TIG welds}

A welded metal comprises of three parts, the fusion zone (FZ), heat affected zone (HAZ) and the base metal (BM) as shown in Figure $2[22,60]$. The FZ or weld metal (WZ) is the region which receives the highest heat during welding, the zone attains the liquidus temperature before it solidifies due to cooling. The FZ is made of the $\alpha$ ' martensitic microstructure, which is majorly responsible for high hardness within the region. Similarly, the HAZ is also made of $\alpha^{\prime}$ martensitic microstructure, but attains a lower temperature, below the liquidus temperature, but mostly attain temperature above the $\beta$ transus temperature of $995^{\circ} \mathrm{C}$ in the case of Ti6Al4V [18]. The BM comprises of the $\alpha$ and $\beta$ phases as reported in [61]. A shining silver appearance is mostly observed in TIG welded Ti6Al4V plates as shown in Figure 3. Reda et al. [22] stated that bead geometry is a function of heat input, the bigger the bead size the higher the heat input and the higher the welding current resulting in larger weld zone (WZ).

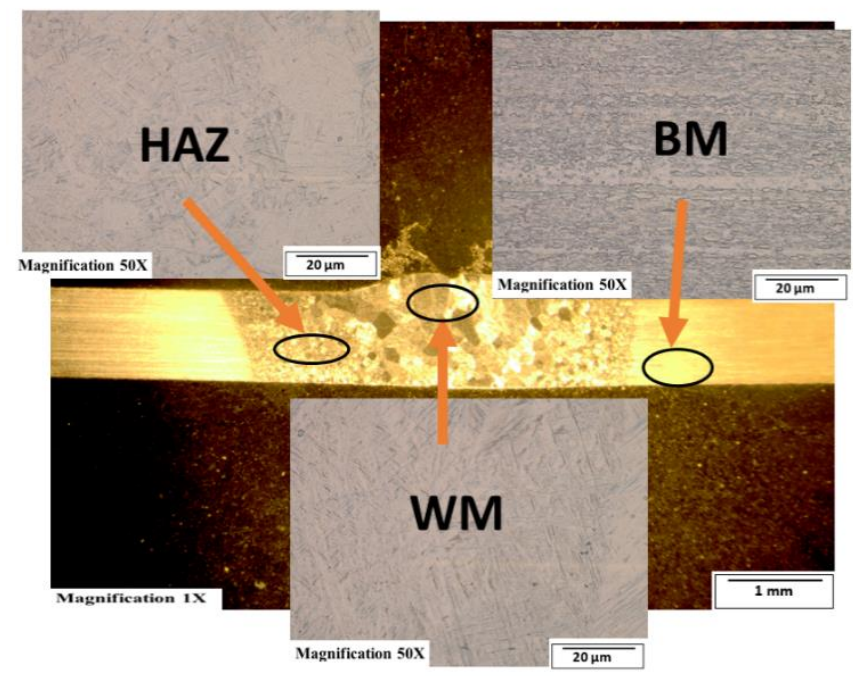

Figure 2. Macrograph showing the three zones of TIG welded metal [62]

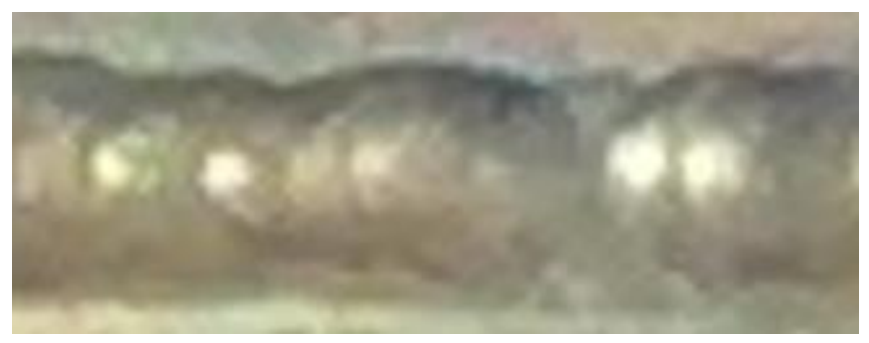

Figure 3. Acceptable TIG weld appearance

\subsection{Weld joint configuration and preparation}

Joint preparation is a factor of the thickness of the metal. In welding of Ti6Al4V alloys, plates with thickness above $3 \mathrm{~mm}$ to undergo butt joint, requires edge preparation, in which a $\mathrm{V}$ groove is created to accommodate proper penetration $[9,63]$. Plates with rough edges tend to increase porosity in the weld. In plates thicker than $6 \mathrm{~mm}$, J groove is used instead of the $\mathrm{V}$ groove to reduce thermal stress within the welded zone. The $\mathrm{J}$ groove angle should not be more than $65^{\circ}$ and not less than $45^{\circ}$ in order to have a consistent and good penetration, it also prevents distortions. In some cases, a double $\mathrm{V}$ joint preparation is used, when there is a need to weld from both sides $[15,64]$.

Acid pickling is fundamentally used in cleaning the metal surface before welding, it is used to remove oxygen and all other contaminations from previous operations before welding. Solution preparations of hydrofluoric and nitric acid of $48 \%$ and $70 \%$ concentration respectively have always been used, with acid concentration ratio ranging from 1:5 to $1: 9$ $(5 \% \mathrm{HF} / 35 \% \mathrm{HNO})$ and acetone have been recommended for pickling of titanium alloys [15]. It is also recommended for pickling to be done at room temperature. 


\subsection{Filler wire specifications}

Filler wire production and usage ranges for different alloys, they are made available in spools or straight length. Filler wires are made to meet some specifications such as surface quality, cleanliness, composition, dimensions and should be same as the base metal [15]. Due to reduced ductility experienced, when using a machined filler wire with Ti6Al4V alloy, an extra-low interstitial (ELI) grade wire is used. After the arc is extinguished, the filler wire should linger on the workpiece with the argon stream touch until both are adequately cooled not to be oxidized. If the filler wire is removed and contaminated, the end must be removed before commencement of a new job.

\subsection{Shielding gas}

Shielding gas is employed in the prevention of contamination and oxidation of welds and slag inclusions, presence of nitrogen in welds results in porosity and brittleness after welding, helium and argon are the frequently used gases in shielding during welding, argon been the cheapest and most readily available is used mostly in Europe and the United States of America, argon gas produces narrower penetration outline, thereby making it useful in making fillets and butt weld [65]. Helium, on the other hand, has high thermal conductivity, due to its ionization potential resulting in higher voltage required to start an arc [56, 66]. Although researchers also combine the two gases (helium and argon) to get good penetration during fusion $[33,56,67]$. Carbondioxide $\left(\mathrm{CO}_{2}\right)$ is also used in short arcs due to its good welding properties, it is cheap and provides safety compared to argon gases. Its major downside is the formation of spatters and cannot be used in spray arc welding.

Gas flow rate is also an important parameter that influences the quality of the weld, a rough thumb rule recommends a gas flow rate in litres per minute to be the same as the inner diameter of the nozzle $[56,68]$.

\subsection{Effects of TIG welding parameters}

TIG welding is being extensively used in industries and due to this, it is necessary to know the effects of different parameters on the mechanical behaviour of Ti6Al4V alloy, to mitigate the cost of welding and to obtain quality weld. Several statistical and experimental techniques have been adopted by researchers to determine the parameters which can be compromised for another in other to have a quality weld, with good mechanical properties. Common methods used in optimizing these parameters are Taguchi method, response surface methodology (RSM), etc. [22, 51, 69, 70], while BoxBehnken, Artificial Neural Network (ANN) have been commonly employed in prediction analysis of these parameters [51, 71]. Furthermore, current pulsing has a significant effect on the parameter selection for TIG welding of Ti6Al4V.

According to Balasubramanian et al. [12], peak current, background current, pulse frequency and pulse on time are major parameters which affect the quality of TIG welds. Pulse frequency is a factor which affects the stress induced in TIG welded Ti6Al4V alloy, increasing pulse frequency, improves the prior $\beta$ grain size within the $\mathrm{FZ}$ when compared to an unpulsed frequency process [16]. Using an unpulsed frequency, there is an increment of prior $\beta$ grain within the FZ and the HAZ, Figure 4 [72]. Furthermore, there is $\alpha^{\prime}$ martensitic microstructure appearance in the form of a thin needle within the prior $\beta$ grains, whereas, in the pulsed mode, $\alpha^{\prime}$ martensite appears in a small plate-like shape within the prior $\beta$ grains.

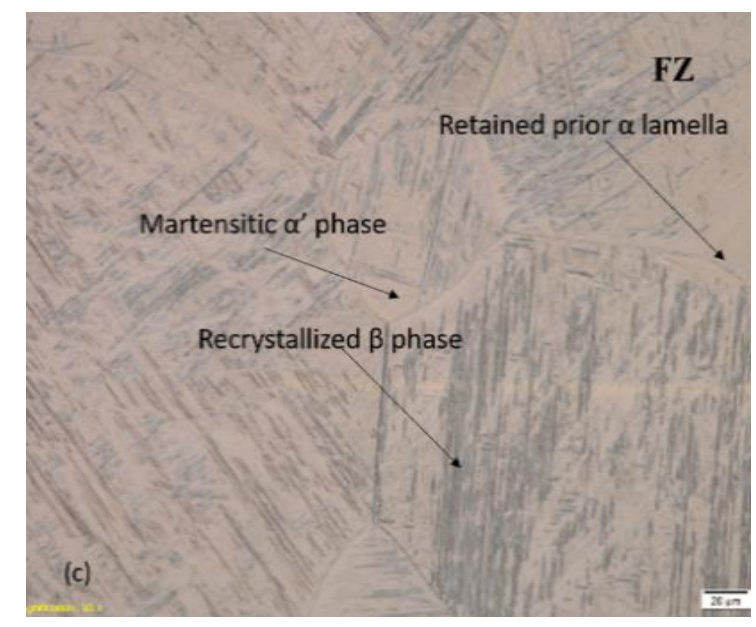

Figure 4. Optical micrograph of unpulsed TIG welding source [72]

The microhardness of TIG welded Ti6Al4V alloy is expected to increase within the weld zone due to the $\alpha$ ' martensitic microstructure present in the zone [73]. The pulsed current mode of TIG welding shows an improved microhardness towards the FZ, likewise the unpulsed, but with a much lower average hardness value compared to pulsed mode, as observed by Mehdi et al. [74]. An increase in pulse frequency, there is a decrease in microhardness within the FZ, due to the prior $\beta$ grains becoming finer compared with the unpulsed technique, it can also be linked with the occurrence of a high amount of residual stress within the FZ [16].

Pulse frequency also have a substantial effect on the tensile properties of TIG welded Ti6Al4V alloys, the ultimate tensile strength (UTS) and ductility are observed to be greater than that of the unpulsed mode [16]. Increasing pulse frequency results in residual stresses within the HAZ and FZ, but lower than what is obtainable in the unpulsed mode. Pulse frequency above $12 \mathrm{~Hz}$ also results in spatter formation [12].

Current also has shown a significant effect on the TIG welding of Ti6Al4V alloys and current should be set with respect to the thickness of the material to be welded. Balasubramanian et al. [12] observed through series of trial welds on $1.6 \mathrm{~mm}$ Ti6Al4V alloy plates, that if peak current is less than $60 \mathrm{~A}$, full penetration is not achievable and results in lack of fusion, but if peak current is set to be greater than 100 A, then undercut or spatter will occur on the bead surface. If background current is lower than $20 \mathrm{~A}$, then arc length becomes very short and when greater than $60 \mathrm{~A}$ it becomes unstable, resulting in arc wandering. Table 1 gives further details on how plate thickness affects the weld penetration.

The effects of welding speed on penetration depth seem not to be as much as that of the current but exhibit an inverse relationship. A fast welding speed above a critical speed limit might result in deterioration of weld and undercuts, as a result of an improper fusion of the welds [58]. Increase in welding speed could cause disorderly weld beads, resulting from the lack of adequate melting time for the proper fusion of the plates, thereby resulting in a decrease of tensile strength [75]. Slower speed could result in lack of proper fusion in Ti6Al4V 
plates [59].

Electrode work distance affects the bead geometry and appearance of weld, the larger the distance from the workpiece, spatter occurs in the weld pool, while a short distance cause undercut. Therefore, information on the optimum electrode work distance should be checked on technical data sheets as specified by manufacturers.

In TIG welding, a significant role has been played by the torch angle in the thermo-mechanical properties of welded Ti6A14V alloy plates. A difference in the angle between $-8^{\circ}$ to $+8^{\circ}$ results in disparity in peak temperature up to $1.8 \%$, even though this does not significantly affect the residual stresses developed in the material, with steeper torch angle, the distortion rate detected in the horizontal plate becomes smaller while that of the vertical plate increases [52].

Figure 5 describes the effect of various parameters on the weld quality, it summaries the effects of welding speed, current, and frequency on pulsed TIG welding of thin sheet
Ti6Al4V alloy. The figure summarizes the parameter range which result in lack of weld penetration and parameters which will result to burn through of sheets for thin Ti6Al4V sheets of thicknesses ranging from 1-2 mm. While Table 1 shows the optimum processing parameters achieved by different works in the literature using different statistical tools for TIG welding of Ti6Al4V alloy.
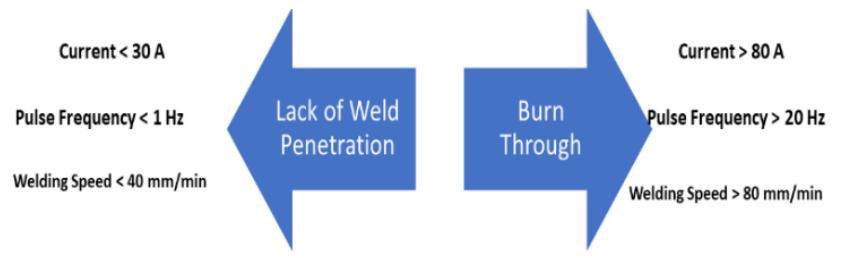

Figure 5. Cause and effect diagram of TIG welding parameters

Table 1. Optimization techniques and optimum parameters achieved for different mechanical properties

\begin{tabular}{|c|c|c|c|c|c|c|c|c|c|c|c|c|c|}
\hline \multirow[t]{2}{*}{ Ref. } & \multirow[t]{2}{*}{ Welding Type } & \multirow{2}{*}{$\begin{array}{l}\text { Optimization } \\
\text { Method used }\end{array}$} & \multirow{2}{*}{$\begin{array}{c}\text { Plate } \\
\text { Size } \\
(\mathrm{mm})\end{array}$} & \multicolumn{6}{|c|}{ Optimum Welding Parameters } & \multirow{2}{*}{$\begin{array}{c}\text { Tensile } \\
\text { Strength } \\
(\mathrm{MPa})\end{array}$} & \multirow{2}{*}{$\begin{array}{c}\% \\
\text { Elongation } \\
(\%)\end{array}$} & \multirow{2}{*}{$\begin{array}{c}\text { Hardness } \\
\text { Value (HV) }\end{array}$} & \multirow{2}{*}{$\begin{array}{c}\text { Impact } \\
\text { Toughness } \\
\text { (J) }\end{array}$} \\
\hline & & & & $\begin{array}{c}\text { Peak } \\
\text { Current } \\
\text { (A) }\end{array}$ & $\begin{array}{c}\text { Base } \\
\text { Current } \\
\text { (A) }\end{array}$ & $\begin{array}{c}\text { Pulse } \\
\text { Frequency } \\
(\mathrm{Hz})\end{array}$ & $\begin{array}{l}\text { Pulse on } \\
\text { Time (s) }\end{array}$ & $\begin{array}{c}\text { Welding } \\
\text { Speed } \\
\left(\mathrm{mmmin}^{-1}\right)\end{array}$ & $\begin{array}{l}\text { Voltage } \\
\text { (V) }\end{array}$ & & & & \\
\hline$[37]$ & Pulsed-TIG & $\begin{array}{c}\text { Response Surface } \\
\text { Methodology }\end{array}$ & 1.20 & 80 & 50 & 12000 & & 60 & & 1005 & & & \\
\hline [76] & Pulsed-TIG & $\begin{array}{c}\text { Weibull } \\
\text { Distribution }\end{array}$ & 1.60 & 80 & 40 & 0 & 45 & & & 980 & 2.4 & & \\
\hline$[50]$ & Pulsed-TIG & Hooke-Jeeves & 1.60 & 83.78 & 48.65 & 6.52 & 43.95 & & & & & & 13 \\
\hline$[77]$ & Pulsed-TIG & Taguchi Method & 1.60 & 80 & 40 & 60 & 45 & & & & & 430 & \\
\hline [67] & $\begin{array}{c}\text { Conventional } \\
\text { TIG }\end{array}$ & Taguchi Method & 6 & 120 & & & & 60 & 18 & 1040 & & & \\
\hline
\end{tabular}

\subsection{Finite element modelling and simulation of TIG welded Ti6Al4V alloy}

One of the recent advances in TIG welding which cannot be overemphasized is the adoption of modelling in the optimization of TIG welding for attainment of optimum mechanical, metallurgical and thermal properties of a weld. It is beneficial to planning and reduction of time and resources in experimenting. Several researchers have used this approach to solve several engineering problems in welding. The finite element method (FEM) analysis are performed in two steps, the thermal and mechanical analysis [78] the previous involves heat transfer which is modelled using the transient heat transfer equation for two and three-dimensional heat flow [79] shown in Eqns. (1) and (2) respectively, the equation was first presented by Rosenthal in 1941 [80, 81], the equation is without some limitations and assumptions such as consideration of heat dissipation by conduction under equilibrium conditions, disregard of convection losses in the dynamic molten pool and surface radiation, lack of phase transformation enthalpy.

$$
\begin{gathered}
T-T_{0}=\frac{P}{2 \pi K} e^{v x / 2 \pi} K_{0}\left(\frac{v R}{2 \alpha}\right) \\
T-T_{0}=\frac{P}{2 \pi K R} e^{-v \frac{(R-x)}{2 x}}
\end{gathered}
$$

$R$ is the radial distance from the weld centerline, $R=$ $\sqrt{x^{2}+y^{2}}$ or $R=\sqrt{x^{2}+y^{2}+z^{2}}$ for $2 \mathrm{D}$ and 3D heat flow respectively $(\mathrm{m})$.

$\alpha$ is the thermal diffusivity of the material $\left(\mathrm{m}^{2} \mathrm{~s}^{-1}\right)$.

Eagar and Tsai's model reported by Dhinakaran et al. [81] accounts for a more accurate model for temperature distribution during welding, the Gaussian distribution for the heat source travelling on the surface of a semi-infinite plate was considered and is shown in Eq. (3).

$$
d T_{i}=\left(\frac{q d t}{\rho C \pi \sqrt{4 \pi a\left(t-t^{t}\right)}}\right)\left(\frac{1}{4 a\left(t-t^{t}\right)+2 \sigma^{2}}\right)\left(\exp \left(-\frac{x^{2}+y^{2}}{4 a\left(t-t^{\prime}\right)+2 \sigma^{2}}-\frac{z^{2}}{4 a\left(t-t^{\prime}\right)}\right)\right)
$$

The heat source is mostly modelled using the general double ellipsoidal shape and could be in done in $2 \mathrm{D}$ or $3 \mathrm{D}$, heat input is calculated using Eq. (4).

$$
H I=\eta \frac{Q}{v}
$$

The mechanical analysis is basically modelled using the momentum equation. Reda et al. [22] used the finite element method (FEM) to optimize the welding current using the Gaussian distribution of power in space, which was built using the ABAQUS software, in which a double ellipsoid model was used for the heat source. Results show that welding current ranging from 130-170 $\mathrm{A}$ is suitable for penetration of the 12 
mm thick plate, with longitudinal and transverse residual stress being reliant on the welding current and longitudinal residual stresses being greater than the transverse stress. $130 \mathrm{~A}$ was observed to be the optimum weld current to give low residual stress. Zhang et al. [82] also optimized TIG welding current using FEM with ABAQUS software, the Gaussian heat source model was adopted, which accounts for the heat loss through radiation and convection, the microstructural evolution was analyzed using the macro-micro cellular automation-finite different method, results of the microstructures show coarse columnar grains as the heat input rises, resulting in brittleness of the metal.

\section{MICROSTRUCTURE AND MECHANICAL PROPERTIES OF TIG WELDED TI6AL4V ALLOY}

\subsection{Microstructure evolution of TIG welded Ti6Al4V alloys}

Generally, Ti6Al4V alloy microstructure is made of the white granular $\beta$ and the black equiaxed $\alpha$, and the morphology and size of $\alpha$ colonies contribute to various mechanical properties of Ti6Al4V alloys $[22,25,33,58]$, reducing the $\alpha$ colonies through the use of various thermo-mechanical processes improves fatigue crack nucleation resistance, toughness, ductility, yield strength, while poor ductility has been attributed to the large heat input and larger $\beta$ grain size growth $[1,16,22,58]$. Within the FZ, there exist acicular $\alpha$ ' and some secondary $\alpha$ morphology at the boundaries of prior $\beta$ due to low cooling rate $[9,25,74]$. The microstructure within the HAZ consist of martensitic $\alpha$ ' and $\alpha$ phase within the prior $\beta$ grains, with increasing distance from the HAZ, the smaller $\beta$ grains turn out to be less equiaxed and reduces in size. There is also a gradient of prior $\beta$ grain sizes spreading from the FZ/HAZ to the HAZ/BM margin [2, 9, 33]. Table 2 summaries the microstructure evolution in TIG welded Ti6Al4V alloy from the BM through the HAZ and the FZ.

Table 2. Microstructure evolution in TIG welded Ti6Al4V alloy

\begin{tabular}{cc}
$\begin{array}{c}\text { Weld } \\
\text { Region }\end{array}$ & Microstructure \\
\hline BM & White granular $\beta$ and the black equiaxed $\alpha$ \\
HAZ & $\alpha$ phase and martensitic $\alpha$ ' within the prior $\beta$ grains \\
FZ & Acicular $\alpha$ ' and some second $\alpha$ morphology at the \\
boundaries of prior $\beta$
\end{tabular}

\subsection{Microhardness evaluation of TIG welded Ti6Al4V alloy}

Generally, hardness is taken in the three zones of test samples (BM, HAZ, FZ), microhardness evolution is known to increase from the BM towards the HZ [33]. This growth is explained by the presence of $\alpha^{\prime}$ martensite in the FZ and HAZ and the hardening effect as a result of the existence of oxygen in the HAZ and FZ $[22,58,74]$. The refinement of the grain size of prior $\beta$ within the FZ and HAZ is also attributed to the high hardness occurrence as shown in Figure 6.

Gao et al. [1] reported an average of $311 \mathrm{HV}$ and $342 \mathrm{HV}$ within the FZ and HAZ respectively. Babu and Raman [16] observed microhardness within the base metal as $309 \mathrm{HV}$ and the HAZ ranging from 345-352 HV. In post-weld heat treated (PWHT) samples of Ti6Al4V alloy at $900^{\circ} \mathrm{C}$, there exist reduced hardness compared to the as-received welded plates due to the decomposition of $\alpha^{\prime}$ to equilibrium products of $\alpha$ and $\beta$ and a decline in defect density.

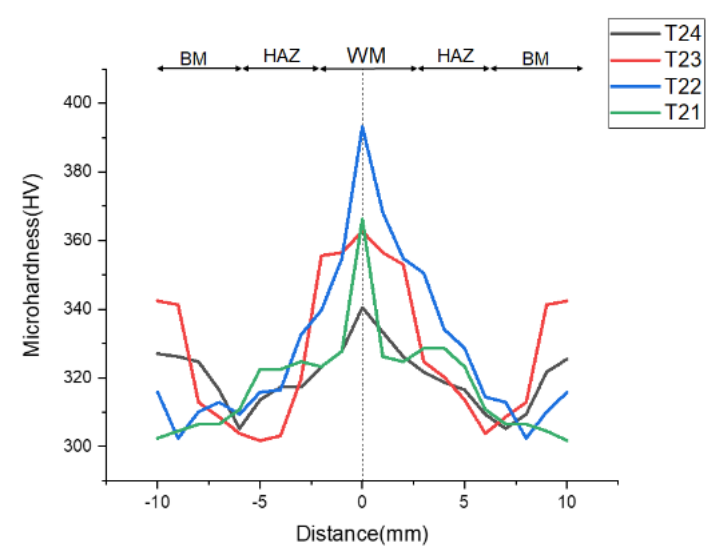

Figure 6. Microhardness of TIG welded samples source [62]

\subsection{Tensile strength of TIG welded Ti6aAI4V alloy}

The region of failure after the tensile test is said to be the weak point of the weld, the tensile strength at failure is compared to the strength of the BM. Ultimate tensile strength (UTS) is found to increase within the FZ and HAZ than the $\mathrm{BM}$ due to the fine microstructure in this zone, poor ductility in FZ is attributed to the large prior $\beta$ grain size and the large acicular intragranular microstructure [83]. In PWHT Ti6Al4V alloy plates, the UTS decreases as temperature increases, conversely, the elongation increased with temperature increase from the FZ to the BM. Though, the ductility is higher in the BM due to the lenticular $\alpha^{\prime}$ martensite developed. Increase in tensile strength within the weld area could also be attributed to an increase in granule size [25, 67]. Increase in current is also attributed to an increase in tensile strength [22, 75]. Figure 7 shows the range of UTS of welded Ti6Al4V alloy with its percentage elongation from different works of literature that used TIG welding. The UTS ranges from 950$1200 \mathrm{MPa}$, while elongation ranges between 9-14\%.

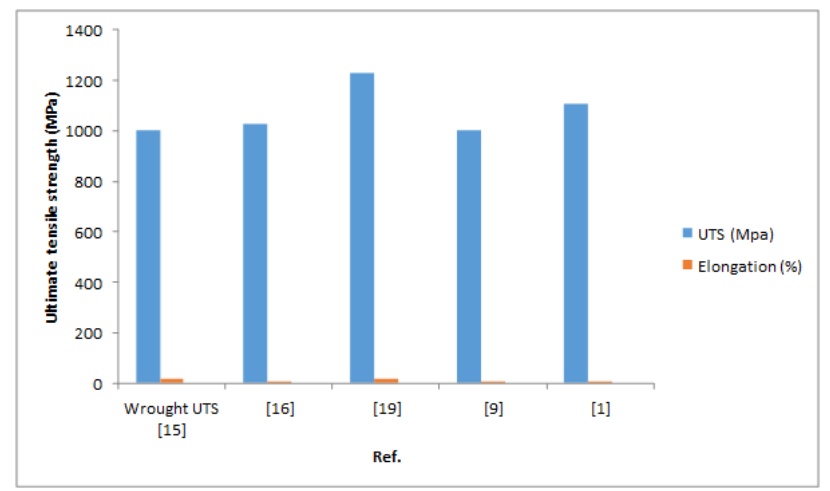

Figure 7. Ultimate tensile strength of some selected works of literature on TIG welding of Ti6Al4V alloy

\subsection{Corrosion behavior of TIG welded Ti6Al4V alloy}

Titanium is known to have a strong affinity for oxygen, the oxygen forms a protective coat at the surface of the metal, thereby making it corrosion resistant [84-86]. When this film (oxide layer) breaks, it becomes highly susceptible to 
corrosion, especially in the reducing agents and oxidizing atmosphere [87]. At $350^{\circ} \mathrm{C}$, there exist challenges to welding of Ti6Al4V alloy due to its high affinity for oxygen and nitrogen. These impurities in the form of oxidation results in a reduction in ductility and toughness [38].

Weldments of titanium alloys exhibit corrosion resistance comparable to that of the base metal, but in cases or environments where there is active corrosion exceeding 100 $\mu$ myear $^{-1}$, a welded portion may undergo quicker corrosion due to the transformed $\beta$ phase associated with the HAZ.

In the petrochemical industry where Ti6Al4V alloys are being widely used, there occurs localized corrosion, which appears in the form of pitting or crevice, in the multi-step process. According to Sabet et al. [88], localized corrosion is divided into four steps, which are absorption of reactive anion on the oxide covered titanium, secondly, there is a chemical reaction of the absorbed anion with the titanium ion in the titanium oxide lattice, thirdly, thinning of the oxide occurs through dissolution and lastly, direct attack of the exposed metal by the anion, which is sometimes called pitting propagation. To mitigate the effects of the localized corrosion, it is advised to increase the homogeneity of chemical composition by control of the solidification process, control of residual stress originating from welding, heat treatment of metals. Furthermore, the service atmosphere should be controlled. Due to the coarse grain formation caused by high heat input in TIG welding, metals are susceptible to corrosion, but with a refinement of grain size, results in better corrosion resisting alloy [86].

\subsection{Residual stresses in TIG welded Ti6Al4V alloy}

Residual stress is developed in metals as a result of high temperature gradient resulting in the transformations of microstructure and is known to be disadvantageous to the mechanical properties of titanium alloys. Residual stresses are highest within the FZ and decrease towards the BM due to the heat input in the WZ as shown in Figure 8. Pulsed current TIG welding has also mitigated the level of residual stresses within the WZ because of controlled heat input used in this technique compared to the unpulsed TIG welding [74]. Song et al. [89] observed longitudinal stresses in Ti6Al4V alloy plates of 6 $\mathrm{mm}$, measured at $1.6 \mathrm{~mm}$ below the surface of the workpiece to have the largest tensile stress within the weld area and small compressive strength outside the weld area.

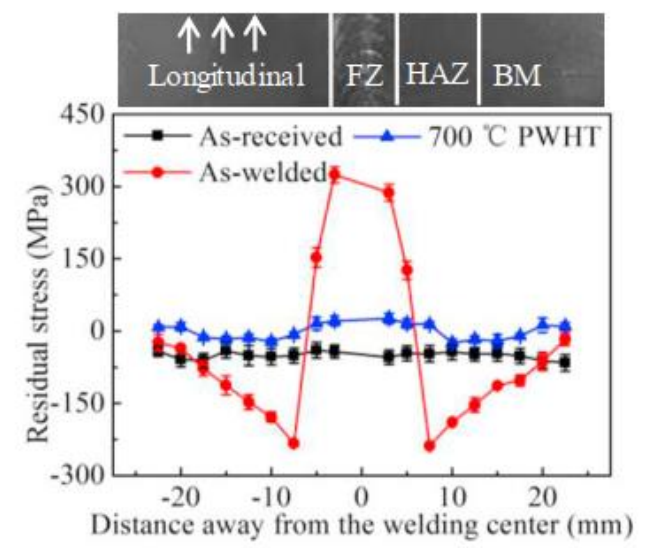

Figure 8. Residual stress distribution source [5]

At a current of $170 \mathrm{~A}$, Reda et al. [22] observed residual stress of $71 \mathrm{MPa}$ for a $12 \mathrm{~mm}$ thick Ti6Al4V alloy plate, longitudinal compressive stresses were also observed in the plates, with magnitudes smaller than the tensile stresses in the FZ, while the transverse residual stresses developed within the FZ are smaller than that of the longitudinal residual stresses. Transverse and longitudinal residual stresses increase with the current increase due to large heat input.

\section{CONCLUSIONS}

Several techniques of metal joining have its unique properties, advantages, and disadvantages, but TIG welding has been proved useful and efficient in joining titanium alloys especially in pulsed mode, due to reduced heat input required compared to the conventional TIG setup. The following conclusions are drawn from this study and are observed to be the major characteristics of TIG welded Ti6Al4V alloy.

1. The microstructural evolution from the BM to $\mathrm{FZ}$ consists of the $\alpha$ phase, transforming to martensitic $\alpha^{\prime}$ within the HAZ and further transformation into acicular $\alpha$ in the FZ.

2. The microhardness of welded alloy increases towards the FZ, i.e., lowest hardness is observed towards the BM.

3. Even though the welded portion exhibits similar corrosion resistance in comparison to the $\mathrm{BM}$, it is more susceptible to corrosion.

4. Longitudinal residual stresses are observed to be high when compared to the transverse residual stress with the FZ of TIG welded Ti6Al4V alloy.

5. Current, pulse frequency and welding speed are the most important parameters to optimize to achieve a quality weld.

For further studies in TIG welding of titanium alloys, there is a need for reduction of residual stresses in a welded joint, to have a more refined microstructure, and improve the mechanical strength of welded metals, therefore, other variants of TIG welding that will reduce the heat input to the minimal level can be developed. Further studies on the failure analysis of the metal should also be conducted to ascertain the integrity of the welds.

\section{REFERENCES}

[1] Gao, X.L., Zhang, L.J., Liu, J., Zhang, J.X. (2013). A comparative study of pulsed Nd: YAG laser welding and TIG welding of thin Ti6Al4V titanium alloy plate. Materials Science and Engineering A, 559: 14-21. https://doi.org/10.1016/j.msea.2012.06.016

[2] Kumar, K., Masanta, M., Kumar Sahoo, S. (2019). Microstructure evolution and metallurgical characteristic of bead-on-plate TIG welding of Ti-6Al-4V alloy. Journal of Materials Processing Technology, 265: 34-43. https://doi.org/10.1016/j.jmatprotec.2018.10.002

[3] Zhang, Y., Huang, J., Ye, Z., Cheng, Z. (2017). An investigation on butt joints of Ti6Al4V and 5A06 using MIG/TIG double-side arc welding-brazing. Journal of Manufacturing Processes, 27: 221-225. https://doi.org/10.1016/j.jmapro.2017.05.010

[4] Chen, C., Fan, C., Cai, X., Lin, S., Liu, Z., Fan, Q., Yang, C. (2019). Investigation of formation and microstructure of Ti-6Al-4V weld bead during pulse ultrasound assisted TIG welding. Journal of Manufacturing Processes, 46(92): 241247. 
[5] Yan, G., Tan, M.J., Crivoi, A., Li, F., Kumar, S., Nicholas Chia, C.H. (2017). Improving the mechanical properties of TIG welding Ti-6Al-4V by post weld heat treatment. Procedia Engineering, 207: 633-638. https://doi.org/10.1016/j.proeng.2017.10.1033

[6] Sen, R., Choudhury, S.P., Kumar, R., Panda, A. (2018). A comprehensive review on the feasibility study of metal inert gas welding. Materials Today: Proceedings, 5(9): 17792-17801.

https://doi.org/10.1016/j.matpr.2018.06.104

[7] Mishra, D., Dakkilli, M., Mangesh, L., Rao, D.K.P. (2016). Multiple response optimization of TIG welding process for optimum weld bead width and reinforcement height of Ti-Alloy (Ti-6al-4v). IOSR Journal of Mechanical and Civil Engineering, 16(053): 84-92. https://doi.org/10.9790/1684-16053028492

[8] Ravikumar, B.V.R., Harshitha, V. (2015). Experimental investigation into the effect of gas tungsten arc welding on ti-6al-4v. International Journal of Advances in Production and Mechanical Engineering (IJAPME), 4: 16.

[9] Cui, S., Shi, Y., Zhu, T., Liu, W. (2019). Microstructure, texture, and mechanical properties of Ti-6Al-4V joints by K-TIG welding. Journal of Manufacturing Processes, 37:

418-424.

https://doi.org/10.1016/j.jmapro.2018.12.022

[10] Gao, X., Dong, J., Han, X. (2017). Effect of $\mathrm{RE}_{2} \mathrm{O}_{3}$ (RE $=\mathrm{La}, \mathrm{Ce})$ fluxes on A-TIG welding of Ti6Al4V. International Journal of Advanced Manufacturing Technology, 91(1-4): 1181-1188. https://doi.org/10.1007/s00170-016-9826-3

[11] Chandramohan, P., Bhero, S., Obadele, B.A., Olubambi, P.A. (2017). Laser additive manufactured Ti-6Al-4V alloy: Tribology and corrosion studies. International Journal of Advanced Manufacturing Technology, 92(58): 3051-3061. https://doi.org/10.1007/s00170-0170410-2

[12] Balasubramanian, M., Jayabalan, V., Balasubramanian, V. (2007). Modeling corrosion behavior of gas tungsten arc welded titanium alloy. Transactions of Nonferrous Metals Society of China (English Edition), 17(4): 676680. https://doi.org/10.1016/S1003-6326(07)60155-1

[13] Cheng, Z., Huang, J., Ye, Z., Yang, J., Chen, S. (2019). Butt brazing of titanium alloys/stainless steel plates by MIG-TIG double-sided arc welding process with copper filler metal. Journal of Materials Research and Technology, $\quad 8(1)$ : $\quad 1566-1570$ https://doi.org/10.1016/j.jmrt.2018.06.009

[14] Wang, F., Williams, S., Rush, M. (2011). Morphology investigation on direct current pulsed gas tungsten arc welded additive layer manufactured Ti6Al4V alloy. International Journal of Advanced Manufacturing Technology, 57(5-8): 597-603. https://doi.org/10.1007/s00170-011-3299-1

[15] TWI. (1999). Guide to best practice-welding titanium, a designers and users handbook. https://docplayer.net/35208305-Guide-to-best-practicewelding-titanium-a-designers-and-users-handbook-tigthe-titanium-information-world-centre-for-materialsjoining-technology.html.

[16] Babu, N.K., Raman, S.G.S. (2006). Influence of current pulsing on microstructure and mechanical properties of Ti-6Al-4V TIG weldments. Science and Technology of Welding and Joining, 11(4): 442-447.
https://doi.org/10.1179/174329306X120750

[17] Omoniyi, P.O., Akinlabi, E.T., Mahamood, R.M. (2021). Microstructural and mechanical properties of laser deposited Ti-6Al-4V Alloy: A review. 4th International Conference on Engineering for a Sustainable World. https://doi.org/10.1088/1757-899X/1107/1/012110

[18] Omoniyi, P.O., Akinlabi, E.T., Mahamood, R.M. (2021). Heat treatments of Ti6Al4V alloys for industrial applications: An overview. 4th International Conference on Engineering for a Sustainable World.

[19] Muth, T.R., Yamamoto, Y., Frederick, D.A., Contescu, C.I., Chen, W., Lim, Y.C., Peter, W. H., Feng, Z. (2013). Causal factors of weld porosity in gas tungsten arc welding of powder-metallurgy-produced titanium alloys. JOM, 65(5): 643-651. https://doi.org/10.1007/s11837013-0592-5

[20] Das, R., Clearly, P. (2009). Investigation of flow dynamics and plastic deformation in Arc. 7th International Conference on CFD in the Minerals and Process Industries, 12: 1-6.

[21] Muncaster, P.W. (1991). A Practical Guide to TIG (GTA) Welding. 1st Edition. https://www.elsevier.com/books/apractical-guide-to-tig-gta-welding/muncaster/978-185573-020-5.

[22] Reda, R., Magdy, M., Rady, M. (2019). Ti - 6Al - 4V TIG weld analysis using FEM simulation and experimental characterization. Iranian Journal of Science and Technology, Transactions of Mechanical Engineering, $\quad 44($ Part $\quad$ B): https://doi.org/10.1007/s40997-019-00287-y

[23] Turichin, G., Tsibulsky, I., Somonov, V., Kuznetsov, M., Akhmetov, A. (2016). Laser-TIG welding of titanium alloys. IOP Conference Series: Materials Science and Engineering, 142(1). https://doi.org/10.1088/1757899X/142/1/012009

[24] Sun, Z., Lv, Y., Xu, B., Liu, Y., Lin, J., Wang, K. (2015). Investigation of droplet transfer behaviours in cold metal transfer (CMT) process on welding Ti-6Al-4V alloy. The International Journal of Advanced Manufacturing Technology, 80: 2007-2014. https://doi.org/10.1007/s00170-015-7197-9

[25] Su, X., Tao, W., Chen, Y., Fu, J. (2018). Microstructure and tensile property of the joint of Laser-MIG hybrid welded thick-section TC4 alloy. Metals, 8(12): 1002. https://doi.org/10.3390/met8121002

[26] Moradi, M., Ghoreishi, M., Khorram, A. (2018). Process and outcome comparison between laser, tungsten inert gas (TIG) and laser-TIG hybrid welding. Lasers in Engineering, 39(3-6): 379-391.

[27] Chen, G., Ma, Z., Liu, C. (2016). Investigation of the benefits of pulse current for the additive manufacture of Ti-6Al-4V. Proceedings of the 2016 5th International Conference on Environment, Materials, Chemistry and Power Electronics, pp. 346-350. https://doi.org/10.2991/emcpe-16.2016.74

[28] Afolalu, S.A., Ikumapayi, O.M., Ogedengbe, T.S., Emetere, M.E. (2021). Performance assessment of the developed flux powder on the tensile and hardness properties of steels joints using TIG-welding. Revue des Composites et des Matériaux Avancés-Journal of Composite and Advanced Materials, 31(3): 153-157. https://doi.org/10.18280/rcma.310306

[29] Gupta, K., Laubscher, R.F. (2017). Sustainable machining of titanium alloys: A critical review. 
Proceedings of the Institution of Mechanical Engineers, Part B: Journal of Engineering Manufacture, 231(14): 2543-2560. https://doi.org/10.1177/0954405416634278

[30] Gope, D.K., Kumar, U., Chattopadhyaya, S., Mandal, S. (2018). Experimental investigation of pug cutter embedded TIG welding of Ti-6Al-4V titanium alloy. Journal of Mechanical Science and Technology, 32(6): 2715-2721. https://doi.org/10.1007/s12206-018-0528-7

[31] Hanuma, P., Prasad, S.K. (2019). Finite element analysis of weld bead geometry of micro plasma arc welding titanium (Ti-6al-4v) Alloy. Journal of Material Science \& Manufacturing Technology, 4(2): 38-57. http://doi.org/10.5281/zenodo.3372381

[32] Antunes, R.A., de Oliveiraa, M.C.L., Salvador, C.A.F. (2018). Materials selection of optimized titanium alloys for aircraft applications. Materials Research, 21(2). https://doi.org/10.1590/1980-5373-mr-2017-0979

[33] Gope, D.K., Kumar, U., Chattopadhyaya, S., Mandal, S., (2018). Investigation into the TIG welded joint of titanium G-5 alloy sheet Investigation into the TIG welded joint of titanium G-5 alloy sheet. International Conference on Mechanical and Renewable Energy, IOP Publishing, 377(1): 012114 https://doi.org/10.1088/1757-899X/377/1/012114

[34] Ahmed, Y.M., Sahari, K.S.M., Jhidhir, B.A., Ishak, M. (2015). Study of mechanical properties on thick titanium alloy (Ti - 6Al- 4V) multi-passes weld. Journal of Multidisciplinary Engineering Science and Technology (JMEST), 2(4): 660-665. http://umpir.ump.edu.my/id/eprint/11709/7/fkm-2015mishak-Study\%20of\%20Mechanical\%20Properties.pdf.

[35] Babu, M.R., Vempati, S., Srinivasulu, R. (2018). Analyzing the geometrical parameters of $\mathrm{Ti} 6 \mathrm{Al} 4 \mathrm{~V}$ welded joint subjected to fatigue load using RSM technique. International Journal of Innovative Research in Science, Engineering and Technology, 7(5): 48584865. https://doi.org/10.15680/IJIRSET.2018.0705064

[36] Dewangan, S., Mohapatra, S.K., Sharma, A. (2020). An assessment into mechanical properties and microstructural behavior of TIG welded Ti-6Al-4V titanium alloy. Grey Systems: Theory and Application 10(3): 281-292. https://doi.org/10.1108/gs-11-20190052

[37] Vaithiyanathan, V., Balasubramanian, V., Malarvizhi, S., Petley, V., Verma, S. (2020). Combined effect of gas tungsten arc welding process variants and post-weld heat treatment on tensile properties and microstructural characteristics of Ti-6Al-4V alloy joints. Metallography, Microstructure, and Analysis, 9(2): 194-211. https://doi.org/10.1007/s13632-020-00631-8

[38] Junaid, M., Baig, M.N., Shamir, M., Khan, F.N., Rehman, K., Haider, J. (2017). A comparative study of pulsed laser and pulsed TIG welding of Ti-5Al-2.5Sn titanium alloy sheet. Journal of Materials Processing Technology, 242: 24-38. https://doi.org/10.1016/j.jmatprotec.2016.11.018

[39] Ahmed, Y.M., Salleh, K., Sahari, M., Ishak, M. (2012). Welding of titanium (Ti-6Al-4V) alloys: A review. National Graduate Conference, Universiti Tenaga Nasional, Putrajaya Campus, pp. 8-10. https://www.researchgate.net/publication/288991562 Welding_of_Titanium_Ti-6Al-4V_Alloys_A_Review.

[40] Singh, A.K., Dey, V., Rai, R.N. (2017). Techniques to improveweld penetration in TIG welding (A review). Materials Today: Proceedings, 4(2): 1252-1259. https://doi.org/10.1016/j.matpr.2017.01.145

[41] Short, A.B. (2009). Gas tungsten arc welding of $\alpha+\beta$ titanium alloys: A review. Materials Science and Technology, 25(3): https://doi.org/10.1179/174328408X389463

[42] Shah, P., Agrawal, C. (2019). A review on twin tungsten inert gas welding process accompanied by hot wire pulsed power source. Journal of Welding and Joining, 37(2): 41-51. https://doi.org/10.5781/jwj.2019.37.2.7

[43] Akinlabi, S.A., Mashinini, M.P., Abima, C.S., Fatoba, O.S., Akinlabi, E.T. (2019). TIG \& MIG hybrid welded steel joint: A review. Proceedings of the International Conference on Industrial Engineering and Operations Management, pp. 801-811.

[44] Çetkin, E., Çelik, Y.H., Temiz, Ş. (2020). Effect of welding parameters on microstructure and mechanical properties of AA7075/AA5182 alloys joined by TIG and MIG welding methods. Journal of the Brazilian Society of Mechanical Sciences and Engineering, 42(1): 1-12. https://doi.org/10.1007/s40430-019-2119-7

[45] Chen, C., Fan, C., Lin, S., Cai, X., Zhou, L., Ye, S., Yang, C. (2018). Effect of ultrasonic pattern on weld appearance and droplet transfer in ultrasonic assisted MIG welding process. Journal of Manufacturing Processes, 35(92): 368-372. https://doi.org/10.1016/j.jmapro.2018.08.019

[46] Kalaichelvi, V., Karthikeyan, R., Sivakumar, D. (2013). Analysis of gas metal arc welding process using GA tuned fuzzy rule based system. Journal of Intelligent and Fuzzy Systems, 25(2): 429-440. https://doi.org/10.3233/IFS-120650

[47] Liu, H., Cheng, Z., Huang, J., Ye, Z., Yang, J., Chen, S., Zhao, X. (2019). Feasibility study of different filler metals on MIG-TIG double-sided arc brazing of titanium alloy-stainless steel. Journal of Manufacturing Processes, 47:

183-191. https://doi.org/10.1016/j.jmapro.2019.09.029

[48] Ströber, K., Abele, C. (2018). Titanium welding technology for series production. Lightweight Design Worldwide, 11(4): 12-15. https://doi.org/10.1007/s41777-018-0025-9

[49] Zhang, Y., Huang, J., Ye, Z., Cheng, Z., Yang, J., Chen, S. (2018). Influence of welding parameters on the IMCs and the mechanical properties of Ti/Al butt joints welded by MIG/TIG double-sided arc welding-brazing. Journal of Alloys and Compounds, 747: 764-771. https://doi.org/10.1016/j.jallcom.2018.03.119

[50] Balasubramanian, M., Jayabalan, V., Balasubramanian, V. (2006). Optimizing the pulsed current gas tungsten Arc welding parameters. J. Mater. Sci. Technol., 22(6): 821-825.

[51] Balasubramanian, M. (2016). Prediction of optimum weld pool geometry of PCTIG welded titanium alloy using statistical design. Engineering Science and Technology, an International Journal, 19(1): 15-21. https://doi.org/10.1016/j.jestch.2015.06.001

[52] Turner, R. (2017). A finite element model to investigate the impact of torch angle on an autogenous TIG welding process. World Journal of Engineering and Technology, 5(4): 743-753. https://doi.org/10.4236/wjet.2017.54062

[53] Piveta, A.C.G., Montandon, A.A.B., Ricci, W.A., Nagle, M.M. (2012). Mechanical strength and analysis of fracture of titanium joining submitted to laser and tig welding. Materials Research, 15(6): 937-943. 
https://doi.org/10.1590/S1516-14392012005000127

[54] Afolalu, S.A., Ohwofa, A.O., Ongbali, S.O., Ajayi, O.O., Abioye, A.A. (2019). Microstructural and mechanical properties of welded joints in Tig, Mig and friction Stir welding-review. IOP Conference Series: Materials Science and Engineering, 640(1). https://doi.org/10.1088/1757-899X/640/1/012068

[55] Sriram, G., Dhinakaran, V., Jagadeesha, T., Ramgopal, R. (2019). Finite element simulation of temperature distribution and residual stress in single bead on plate weld trial using double ellipsoidal heat source model. International Journal of Recent Technology and Engineering, 8(1): 133-138.

[56] Weman, K., Linden, G. (2006). MIG Welding Guide. Woodhead Publishing in Materials. https://www.elsevier.com/books/mig-weldingguide/weman/978-1-85573-947-5.

[57] Mishra, D. (2017). Response surface optimization of interpulse TIG welding for the optimum weld bead of Ti6Al-4V. International Journal for Research in Applied Science and Engineering Technology, 5(6): 783-790. https://doi.org/10.22214/ijraset.2017.9115

[58] Thomas, G., Ramachandra, V., Nair, M., Nagarajan, K., Vasudevan, R. (1992). Effect of preweld and postweld heat treatment on the properties of GTA welds in Ti-6Al4V sheet. Welding Journal, 71(1): 15s-20s.

[59] Mishra, D., Manjunath, A., Parthiban, K. (2017). Interpulse Tig welding of titanium alloy (TI-6Al-4V). Indian Welding Journal, 50(4): 56. https://doi.org/10.22486/iwj/2017/v50/i4/162271

[60] Soltani, S., Eghtesad, M., Bazargan-Lari, Y. (2020). Mass and heat transfer control in the GMAW process utilizing feedback linearization and sliding mode observer. International Communications in Heat and Mass $\quad$ Transfer, 111: 104410 https://doi.org/10.1016/j.icheatmasstransfer.2019.10441 0

[61] Omoniyi, P.O., Mahamood, R.M., Akinlabi, E.T. (2021). Impact of process parameters of laser welding on the mechanical properties of Ti6Al4V: A review. Journal of Chemical Technology and Metallurgy, 56(5): 1074-1781.

[62] Omoniyi, P., Mahamood, M., Jen, T., Akinlabi, E. (2021). TIG welding of Ti6Al4V alloy: Microstructure, fractography, tensile and microhardness data. Data in Brief, 38

107274 https://doi.org/10.1016/j.dib.2021.107274

[63] Miao, Y., Ma, Z., Yang, X., Liu, J., Han, D. (2018). Experimental study on microstructure and mechanical properties of AA6061/Ti-6Al-4V joints made by bypasscurrent MIG welding-brazing. Journal of Materials Processing Technology, 260: 104-111. https://doi.org/10.1016/j.jmatprotec.2018.05.019

[64] Campus, G., Post, J., State, K. (2012). Optimization of shielded metal arc welding parameters for welding of pipes by using Taguchi approach. International Journal of Engineering Science and Technology, 4(5): 2083 2088.

[65] Hoye, N., Li, H., Norrish, J., Dippenaar, R. (2012). Postweld atmospheric contamination of gas tungsten arc deposited welds in commercially pure and Ti-6A1-4V titanium alloys. Ti 2011 - Proceedings of the 12th World Conference on Titanium, 2: 1629-1633.

[66] Vaidya, S., Kumar, A., Hitesh, S., Narsia, A. (2018). Importance of various shielding gases used in TIG welding for exotic materials in aerospace industry. Indian Welding Society, 15: 2017-2019. https://doi.org/10.22201/fq.18708404e.2004.3.66178

[67] Reddy Vempati, S., Brahma Raju, K., Venkata Subbaiah, K. (2018). Optimization of Welding Parameters of Ti 6al $4 \mathrm{v}$ Cruciform shape Weld joint to Improve Weld Strength Based on Taguchi Method. Materials Today: Proceedings, 5(2): 4948-4957. https://doi.org/10.1016/j.matpr.2017.12.072

[68] Karpagaraj, A., Siva Shanmugam, N., Sankaranarayanasamy, K. (2019). Experimental investigations and numerical prediction on the effect of shielding area and post flow time in the GTAW of CP Ti sheets. International Journal of Advanced Manufacturing Technology, 101(9-12): 2933-2945. https://doi.org/10.1007/s00170-018-3135-y

[69] Singh, S., Saini, T.S. (2017). Optimization of quality of energy consumption and some weld quality response parameters in gas tungsten arc welding. International Journal of Latest Trends in Engineering and Technology, 69-76 https://www.ijltet.org/pdfviewer.php?id=925\&j_id=423

[70] Pasupathy, J., Ravisankar, V. (2013). Parametric optimization of tig welding parameters using Taguchi method for dissimilar Joint. International Journal of Scientific \& Engineering Research, 4(11): 25-28.

[71] Karimzadeh, F., Salehi, M., Saatchi, A., Meratian, M. (2005). Effect of microplasma arc welding process parameters on grain growth and porosity distribution of thin sheet Ti6Al4V alloy weldment. Materials and Manufacturing Processes, 20(2): 205-219. https://doi.org/10.1081/AMP-200041857

[72] Omoniyi, P.O., Mahamood, R.M., Arthur, N., Pityana, S. Akinlabi, S.A., Hassan, S., Okamoto, Y., Maina, M.R., Akinlabi, E.T. (2021). Investigation of the mechanical and microstructural properties of TIG welded Ti6Al4V alloy. Advances in Material Science and Engineering: Selected articles from ICMMPE, 111-118.

[73] Beris, B. (2012). Effects of gas shielding flow rate on weld quality of TIG weldind in Ti6Al4V alloy. Instabul Technical University.

[74] Mehdi, B., Badji, R., Ji, V., Allili, B., Bradai, D., Deschaux-Beaume, F., Soulie, F. (2016). Microstructure and residual stresses in Ti-6Al-4V alloy pulsed and unpulsed TIG welds. Journal of Materials Processing Technology, 231: 441-448. https://doi.org/10.1016/j.jmatprotec.2016.01.018

[75] Prakash, C., Singh, S., Singh, M., Gupta, M.K., Mia, M., Dhanda, A. (2019). Multi-objective parametric appraisal of pulsed current gas tungsten arc welding process by using hybrid optimization algorithms. International Journal of Advanced Manufacturing Technology, 101(14): 1107-1123. https://doi.org/10.1007/s00170-0183017-3

[76] Balasubramanian, M. (2016). Statistical analysis of tensile strength and elongation of pulse TIG welded titanium alloy joints using Weibull distribution. Cogent Engineering, $3(1)$. https://doi.org/10.1080/23311916.2016.1239298

[77] Balasubramanian, M., Jayabalan, V., Balasubramanian, V. (2011). Application of Taguchi method in process parameter selection of PCTIG titanium welds. Journal for Manufacturing Science and Production, 8(1): 27-32. 
https://doi.org/10.1515/ijmsp.2007.8.1.27

[78] Lindgren, L.E. (2001). Finite element modeling and simulation of welding part 1: Increased complexity. Journal of Thermal Stresses, 24(2): 141-192. https://doi.org/10.1080/01495730150500442

[79] Chiumenti, M., Cervera, M., Salmi, A., Agelet de Saracibar, C., Dialami, N., Matsui, K. (2010). Finite element modeling of multi-pass welding and shaped metal deposition processes. Computer Methods in Applied Mechanics and Engineering, 199(37-40): 234359. https://doi.org/10.1016/j.cma.2010.02.018

[80] Oliveira, J.P., Santos, T.G., Miranda, R.M. (2020). Revisiting fundamental welding concepts to improve additive manufacturing: From theory to practice. Progress in Materials Science, 107: 100590. https://doi.org/10.1016/j.pmatsci.2019.100590

[81] Dhinakaran, V., Varsha Shree, M., Jagadeesha, T., Bupathi Ram, P.M., Sathish, T., Stalin, B. (2020). A review on the recent developments in modeling heat and material transfer characteristics during welding. Materials Today: Proceedings, 21: 908-911. https://doi.org/10.1016/j.matpr.2019.08.079

[82] Zhang, M., Zhou, Y., Huang, C., Chu, Q., Zhang, W., Li, J. (2018). Simulation of temperature distribution and microstructure evolution in the molten pool of GTAW Ti-6Al-4V alloy. Materials, 11(11). https://doi.org/10.3390/ma11112288

[83] Becker, D.W., Messler, R.W., Baeslack, W.A., Kohler, C.O., Kohler, W.I. (1980). Titanium welding- a critical review. https://cdn.ymaws.com/titanium.org/resource/resmgr/Z Z-WTCP1980-VOL1/1980_Vol.1-2-

Titanium_Weldin.pdf.

[84] Ishchenko, V., Vasylkivskyi, I. (2020). Sustainable production: Novel trends in energy, environment and material systems. Springer Inter. Publishing, 198: 161175. https://doi.org/10.1007/978-3-030-11274-5

[85] Vinoth, A., Prabu, L., Gokul, B., Ajith Kumar, K. (2016). Effect of shielding gas on titanium CP (Gr- 2) by using gas tungsten Arc welding. International Journal of Engineering Research and Technology, 5(5): 294-300. https://doi.org/10.17577/ijertv5is050210

[86] Ferdinandov, N.V., Gospodinov, D.D., Ilieva, M.D., Radev, R.H. (2018). Structure and pitting corrosion of Ti-6Al-4V alloy and Ti-6Al-4V welds. ICAMS 2018-7 th International Conference on Advanced Materials and SystemsAt: $\quad$ Bucarest, pp. 325-330. https://doi.org/10.24264/icams-2018.vi.7

[87] Razavi, G., Masaeli, M., Taheri, M., Saboktakin, M. (2013). Investigation gas tungsten arc welding of pure titanium. International Journal of Materials and Mechanics Engineering, 2(1).

[88] Sabet, H., Mohammad, N.M., Moniri, Z. (2011). Improving corrosion resistance of Ti-6Al-4V alloy weld metal by grain size refining. Journal of Applied Chemical Research, 17: 59-64.

[89] Song, A.M. Paradowska, P.S. (2014). Investigation of residual stresses distribution in titanium weldments. Mater. Sci. Forum, 777: 171-175. https://doi.org/10.4028/www.scientific.net/MSF.777.17 1

\section{NOMENCLATURE}

$T \quad$ the temperature at a given point $(\mathrm{K})$

$T_{0} \quad$ the initial temperature of the base metal $(\mathrm{K})$

$P \quad$ the welding power (W)

$K \quad$ the thermal conductivity of the material $\left(\mathrm{Wm}^{-1} \mathrm{~K}^{-1}\right)$

$v \quad$ the welding speed $\left(\mathrm{ms}^{-1}\right)$

$x \quad$ the distance from the heat source $(\mathrm{m})$

$K_{0} \quad$ the modified Bessel function of the second kind and zero-order

HI the heat input $\left(\mathrm{Jmm}^{-1}\right)$

$\eta \quad$ the efficiency of power transfer (\%)

$Q \quad$ the welding power (W)

$\mathrm{V}$ the welding speed $\left(\mathrm{ms}^{-1}\right)$ 